\title{
Properties of Geopolymers Made from Fired Clay Bricks Wastes and Rice Husk Ash (RHA)-Sodium Hydroxide ( $\mathrm{NaOH}$ ) Activator
}

\author{
Lynn Myllyam Beleuk à Moungam, Hawa Mohamed, Elie Kamseu, Ndigui Billong*, \\ Uphie Chinje Melo
}

Laboratory of Material Analysis, MIPROMALO, Yaoundé, Cameroon

Email: *nbillong@yahoo.fr

How to cite this paper: Beleuk à Moungam, L.M., Mohamed, H., Kamseu, E., Billong, N. and Melo, U.C. (2017) Properties of Geopolymers Made from Fired Clay Bricks Wastes and Rice Husk Ash (RHA)Sodium Hydroxide $(\mathrm{NaOH})$ Activator. $M a$ terials Sciences and Applications, 8, 537552.

https://doi.org/10.4236/msa.2017.87037

Received: March 14, 2017

Accepted: July 2, 2017

Published: July 5, 2017

Copyright $(9) 2017$ by authors and Scientific Research Publishing Inc. This work is licensed under the Creative Commons Attribution International License (CC BY 4.0).

http://creativecommons.org/licenses/by/4.0/

\begin{abstract}
High cost has been pointed among factors that limit the promotion of geopolymers. To contribute to the reduction of the use of costly industrial sodium silicate in activators for geopolymers, a gel obtained with RHA and concentrated sodium hydroxide was used in the present study to develop an alkaline activator with $8 \mathrm{M} \mathrm{NaOH}$ and to produce geopolymers with crushed fired clay bricks wastes (FCBW). Characteristics of the gel were compared to that of commercial sodium silicate which was also mixed with $8 \mathrm{M} \mathrm{NaOH}$ in the ratio 1:1 to produce geopolymers. Chemical and mineralogical analyses were done on raw materials. Fourier Transformed Infrared Spectroscopy (FTIR) was done on the gel, commercial sodium silicate and products. Biaxial four point flexural strength, bulk density, water absorption and scanning electron microscopy (SEM) tests were also done on products. Results showed that RHA-NaOH alkaline activator has good potential in consolidating FCBW powder through geopolymerization process which gave products that had characteristics not far from that when the commercial sodium silicate was used. The gel obtained by mixing $\mathrm{RHA}$ and $\mathrm{NaOH}$ can contribute to the reduction of the use of costly commercial sodium silicate in the production process of geopolymers. However, appropriate filtration process is needed for the RHA- $\mathrm{NaOH}$ gel to reduce its impurities as undissolved entities, which will consequently contribute to improve the flexural strength, the density and the microstructure of its products which were low compared to when commercial sodium silicate was used.
\end{abstract}

\section{Keywords}

Rice Husk Ash, Sodium Hydroxide, Fired Clay Bricks Waste, Geopolymer, Sustainability 


\section{Introduction}

Concrete is the most used material worldwide in construction because of its multiple technical advantages [1]. However, the production of Portland cement which is one of its components leads to the emission of significant quantities of greenhouse gases [2]. That is why, for decades, researchers have been developing substitutes to Portland cement. Binders made from activated aluminosilicates by alkaline solution also called geopolymer represent an attractive alternative [3] [4]. The term "geopolymer" was first used in 1972 by Joseph Davidovits [4]. Geopolymers are assimilated to mineral polymers exhibiting good mechanical properties, good resistance to high temperature and to acid attack. Geopolymers are used in their pure state, charged or reinforced and they are applied where traditional materials (metals, ceramics, organic polymers) do not yield satisfactory results especially in the industrial sector such as foundry, metallurgy, civil engineering, waste management and aviation industry [5]. The geopolymerization's reaction is done at temperatures close to the ambient between an aluminosilicate material and an alkaline silicate solution [5] [6]. The commonly used aluminosilicates are metakaolin [7] and fly ash [8]. In recent years, for environmental concerns, by-products, containing alumina and silica were also increasingly used. They can be volcanic ash [9] and ceramic wastes [10]. The conventionally used alkaline activator is a mixture of sodium $(\mathrm{NaOH})$ or potassium $(\mathrm{KOH})$ hydroxide with sodium $\left(\mathrm{Na}_{2} \mathrm{SiO}_{3}\right)$ or potassium $\left(\mathrm{K}_{2} \mathrm{SiO}_{3}\right)$ silicate [11]. The constituents of these alkaline solutions are manufactured products. Sodium silicate, for example, is currently obtained industrially by melting sand with sodium carbonate at high temperature between $1300^{\circ} \mathrm{C}-1500^{\circ} \mathrm{C}$ [12] [13]. This manufacturing process consumes large amount of energy and produces considerable air pollutants such as dust, nitrogen oxide and sulfur oxide [13]. For geopolymers to be a viable alternative and industrially interesting, many technological issues must be overcome, especially research on low cost activators. In this direction, Zivica developed alkaline activators based on silica fume [14]. In the same manner, agro-industrial by-products have been the subject of several investigations regarding the manufacture of sodium silicate [4]. Thus, sodium silicate can be obtained by reacting concentrated aqueous sodium hydroxide with siliceous products derived from agricultural by-products such as sugar cane bagasse [15] and rice husk [12]. Rice husk (RH) is an important residue derived from rice paddy that represents about $20 \%$ of its mass [16]. Hence, it leads to serious environmental pollution issues derived from its disposal. RHA contains more than $60 \%$ of silica [12] [13]. The nature of this silica depends on the burning temperature. It is reported that between $500^{\circ} \mathrm{C}-700^{\circ} \mathrm{C}$, the silica in RHA remains amorphous [17] and very reactive in the presence of alkaline solutions. RHA has been widely used in many construction and civil engineering applications [18] [19] [20].

The aim of this study is to investigate the properties of geopolymer products obtained by the alkali-activation of FCBW powder with an alkaline solution obtained by mixing RHA, sodium hydroxide and water. Raw materials and products 
were characterized using the following analytical methods: X-Ray Diffraction (XRD), X-Ray Fluorescence (XRF), Fourier Transform Infra-Red Spectroscopy (FTIR), Bi-axial Four Point Flexural Strength and Scanning Electron Microscopy (SEM). Bulk density and water absorption tests were also done on hardened products.

\section{Materials and Experimental Procedure}

\subsection{Materials Used in Study}

A large amount of broken fired clay bricks considered as waste is obtained after firing activities, transportation or construction with this material [21]. The sample of FCBW used was collected from the fired bricks factory of the Local Materials Promotion Authority (MIPROMALO), in Yaounde (Cameroon). This factory has a yearly brick production of 3750 tons of fired bricks with $17 \%$ of breaks. A small amount of this waste is crushed at the factory as chamot and the huge part dumped in open fields, causing damage to the land and serious disposal problems. The as-received FCBW were pulverized at $500 \mu \mathrm{m}$ in an industrial crusher and divided into two parts: the first was kept as it was and the second was ball milled to increase its fineness and sieved completely at $200 \mu \mathrm{m}$ before use.

RHA is from RH collected from a rice milling factory in Ndop, a locality situated in the North-West region of Cameroon. In this factory, the husk is treated as a waste material and burned in open-air, causing damage to the environment due to fine particles and greenhouse gas emissions. A sample of the husk was thoroughly washed to remove dust and other solid particles then dried in the oven at $105^{\circ} \mathrm{C}$ for 24 hours. The dried husk was then burned at $700^{\circ} \mathrm{C}$ for 2 hours in a muffle furnace at the heating rate of $10^{\circ} \mathrm{C} / \mathrm{min}$. When cooled, the ash was ball milled and sieved completely at $80 \mu \mathrm{m}$. The chemical analysis of RHA is indicated in Table 1 .

PROLABO's company, laboratory grade sodium hydroxide pellets (purity 99\%) were used to prepare solutions with distilled water. Commercial sodium silicate $\left(\mathrm{SiO}_{2} / \mathrm{Na}_{2} \mathrm{O}=3.00\right.$ molar ratio; $\mathrm{SiO}_{2}=26.50 \mathrm{wt} \%, \mathrm{Na}_{2} \mathrm{O}=8.70 \mathrm{wt} \%$ and $\mathrm{pH}=11.7$ ) with bulk density of 1.34 at $20^{\circ} \mathrm{C}$, provided by Ingessil, Verona, Italy was also used.

\subsection{Experimental Procedure}

\subsubsection{Synthesis of RHA-NaOH Gel}

The RHA-NaOH gel was prepared based on equation 1 with the aim to obtain a molar ratio of $\mathrm{SiO}_{2} / \mathrm{Na}_{2} \mathrm{O}=3.00(\mathrm{x}=3)$ as in the commercial sodium silicate and using the $\mathrm{SiO}_{2}$ content of RHA that is $93.2 \%$. The calculation shows that $193.1 \mathrm{~g}$ of RHA should be mixed with $200 \mathrm{~mL}$ of $\mathrm{NaOH} 10 \mathrm{M}$ to obtain the gel. In practice with the aim of obtaining a significant amount of the gel, these quantities were multiplied by five. Unfortunately the synthetized gel was too viscous. Distilled water was added in the gel to adjust its density similar to that of the 
Table 1. Chemical composition of FCBW and RHA.

\begin{tabular}{|c|c|c|}
\hline Oxides (\%) & FCBW & RHA \\
\hline $\mathrm{SiO}_{2}$ & 60.98 & 93.2 \\
\hline $\mathrm{Fe}_{2} \mathrm{O}_{3}$ & 9.635 & 0.196 \\
\hline $\mathrm{K}_{2} \mathrm{O}$ & 0.932 & 3.045 \\
\hline $\mathrm{MgO}$ & 0.323 & 0.278 \\
\hline $\mathrm{Al}_{2} \mathrm{O}_{3}$ & 22.5 & 0.584 \\
\hline $\mathrm{CaO}$ & 0.104 & 0.565 \\
\hline $\mathrm{TiO}_{2}$ & 1.728 & 0.033 \\
\hline $\mathrm{P}_{2} \mathrm{O}_{5}$ & 0.331 & 0.498 \\
\hline $\mathrm{MnO}$ & 0.138 & 0.129 \\
\hline $\mathrm{ZnO}$ & 0.019 & 0.0085 \\
\hline $\mathrm{Rb}_{2} \mathrm{O}$ & 0.0044 & 0.0131 \\
\hline $\mathrm{CuO}$ & 0.008 & 0.005 \\
\hline $\mathrm{Na}_{2} \mathrm{O}$ & - & 0.0829 \\
\hline $\mathrm{NiO}$ & 0.0106 & - \\
\hline $\mathrm{Cr}_{2} \mathrm{O}_{3}$ & 0.0251 & - \\
\hline $\mathrm{SrO}$ & 0.0049 & - \\
\hline $\mathrm{V}_{2} \mathrm{O}_{5}$ & 0.0398 & - \\
\hline $\mathrm{ZrO}_{2}$ & 0.06185 & - \\
\hline $\mathrm{SO}_{3}$ & - & 0.0844 \\
\hline $\mathrm{Cl}$ & - & 0.0733 \\
\hline $\mathrm{Br}$ & - & 0.0034 \\
\hline LOI & 3.1 & 1.2 \\
\hline
\end{tabular}

commercial sodium silicate. The final gel was kept in a container with a lid to avoid contact with air.

$$
x \mathrm{SiO}_{2}+2 \mathrm{NaOH} \rightarrow \mathrm{Na}_{2} \mathrm{O}\left(\mathrm{SiO}_{2}\right)_{x}+\mathrm{H}_{2} \mathrm{O}
$$

\subsubsection{Preparation of Activators and Formulation of Geopolymer Samples \\ -Preparation of activators}

To obtain the alkaline activators used in the geopolymer formulations, the commercial sodium silicate and the $\mathrm{RHA}-\mathrm{NaOH}$ gel were each mixed with a solution of $\mathrm{NaOH} 8 \mathrm{M}$ in 1:1 volume ratio. The alkaline activator solutions were named S1, for that having the commercial sodium silicate and S2 for that having the RHA-NaOH gel.

-Formulation of geopolymers

Three series of geopolymers were formulated with 100, 105, 110, 115 and 120 $\mathrm{g}$ of FCBW powder mixed with $60 \mathrm{~mL}$ of $\mathrm{S} 1$ or S2:

- Series A is a mix of unsieved FCBW powder and S1; 
- Series B is a mix of sieved FCBW powder and S1;

- Series C is a mix of sieved FCBW powder and S2.

The obtained pastes were molded in $8 \mathrm{~cm}$ diameter and $3 \mathrm{~cm}$ thickness cylindrical plastic moulds and stored in room temperature for $24 \mathrm{~h}$. After, specimens were removed in molds and kept at ambient temperature for 28 days before testing.

\subsubsection{Characterization of Raw Materials}

Chemical and mineralogical analyses were done on raw materials using respectively a Bruker (S4 PIONER) wave lengths dispersive (WD-XRF) Spectrometer and a Bruker D-8 Advance Diffractometer model operating with a CuKa radiation source $(\lambda=1.5418 \AA)$ and using an acceleration voltage of $40 \mathrm{kV}$ and current of $40 \mathrm{~mA}$. The $2 \theta$ diffraction angle was scanned from $5^{\circ} \mathrm{C}$ to $60^{\circ} \mathrm{C}$, at a rate of $0.02^{\circ} \mathrm{C} / \mathrm{min}$. Interpretation of mineral phases was carried out using EVA software (Diffracplus).

\subsubsection{Characterization of Gels and Products}

The characterization methods of gels and products included:

-Fourier Transform Spectrophotometry using the Attenuated Total Reflection (ATR) method using brukerIFS66v equipment was performed on $\mathrm{RHA}-\mathrm{NaOH}$ gel and commercial sodium silicate then, geopolymer samples underwent Fourier Transformed Infrared Spectroscopy (Avatar 330 FTIR, Thermo Nicolet), analyzing their surfaces and their bulk areas. A minimum of 32 scans between 4000 and $400 \mathrm{~cm}^{-1}$ were averaged for each spectrum at intervals of $1 \mathrm{~cm}^{-1}$.

-Bi-axial four-point flexural strength testing which measures the biaxial flexural strength of hardened samples through the piston on the three balls test. According to Jihwan et al. [22], this test was preferred compared to the uni-axial bending test because thin plates structures such as structural materials for building and construction are subjected to multi-axial stress states due to their complex loading configuration and the geometry structures. The biaxial flexural strength test has an advantage in that it is capable of generating constant equiaxial flexural stress within the area of the loading ring, which is necessary and useful for the investigations of the stochastic nature of the strength of a brittle material. The stress inside the loading ring is identical in all directions, which were modified and Equation (2) was developed for the maximum biaxial flexure strength $\left(\sigma_{\max }\right)$ :

$$
\sigma_{\max }=\frac{3 P(1+v)}{4 \pi t^{2}}+\left[1+2 \ln \left(\frac{a}{b}\right)\right]+\left(\frac{1-v}{1+v}\right)\left(1-\frac{b^{2}}{2 a^{2}}\right) \frac{a^{2}}{R^{2}}
$$

where $P$ is the ultimate sustained load, $a$, is the radius of the support ring, $b$ is the effective radius of contact of the loading ball on the specimen, $R$ is the specimen radius, $t$ is the specimen thickness and $v$ is the Poisson's ratio. Kirstein and Woolley in Jihwan et al. [22] claimed that this solution should approximately be independent from the number of supporting balls, so it can be applied to axi-symmetric but also to non-strictly axi-symmetric testing drying con- 
figurations. Figure 1 gives the schematic display of the four point bending strength equipment used.

-Bulk density of samples was determined according to the American standard ASTM C830-00 [23]. Density values were averages of five experimental results and errors reported as standard deviation from means.

-Water absorption (w) test was carried out by immersing the specimen in water at ambient temperature for $24 \mathrm{~h}$ and comparing the humid weight $(\mathrm{mh})$ to the dry weight (md) of specimens after they were dried for $24 \mathrm{~h}$ at $105^{\circ} \mathrm{C}$ according to Equation (3).

$$
w=\frac{m_{h}-m_{d}}{m_{d}} \times 100
$$

-Scanning Electron Microscopy (SEM) investigations were conducted on a Jeol, mod. 5500 coupled to an EDS probe iXRF system using backscattered electron (BSE). Secondary Electron (SE) imaging was used to study the specimens, which were collected from pieces obtained after the biaxial flexural strength test. The fresh fractured pieces were gold coated to ensure conditions of viability for analytical purposes.

\section{Results and Discussions}

\subsection{Characteristics of Raw Materials}

The chemical composition of raw materials is presented in Table 1. It appears that RHA contains great amounts of silica (93.20\%) and small amounts of other elements considered as impurities. FCBW contains high level of $\mathrm{SiO}_{2}(60.98 \%)$ and $\mathrm{Al}_{2} \mathrm{O}_{3}$ (22.50\%), which are essential for alkali-activation.

The mineralogical composition of RHA is given at Figure 2. XRD pattern of RHA shows a broad band between $15^{\circ}$ and $30^{\circ}, 2 \theta$ diffraction angle, which doesn't corresponds to a defined peak, thereby indicating the amorphous nature of the material [24]. Peaks quartz are observed at $20^{\circ} 92^{\prime}$ and $26^{\circ} 72^{\prime}$ as impurities.

XRD patterns of FCBW (Figure 3 ) indicated the presence of an amorphous material which could be metakaolin developed during the firing process of clay

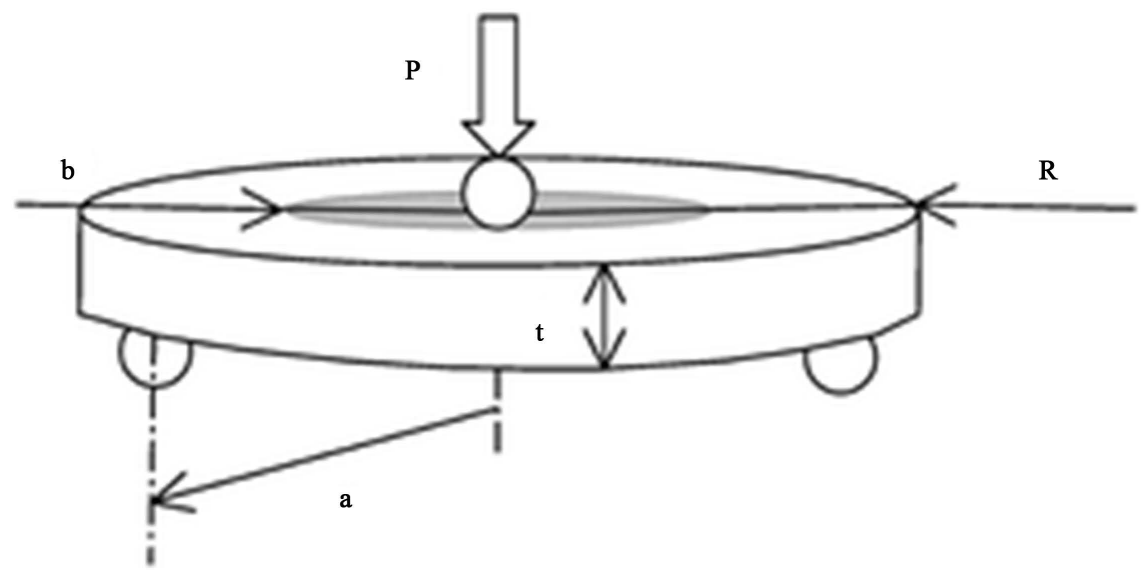

Figure 1. Schematic display of the bi-axial four-point flexural strength equipment. 


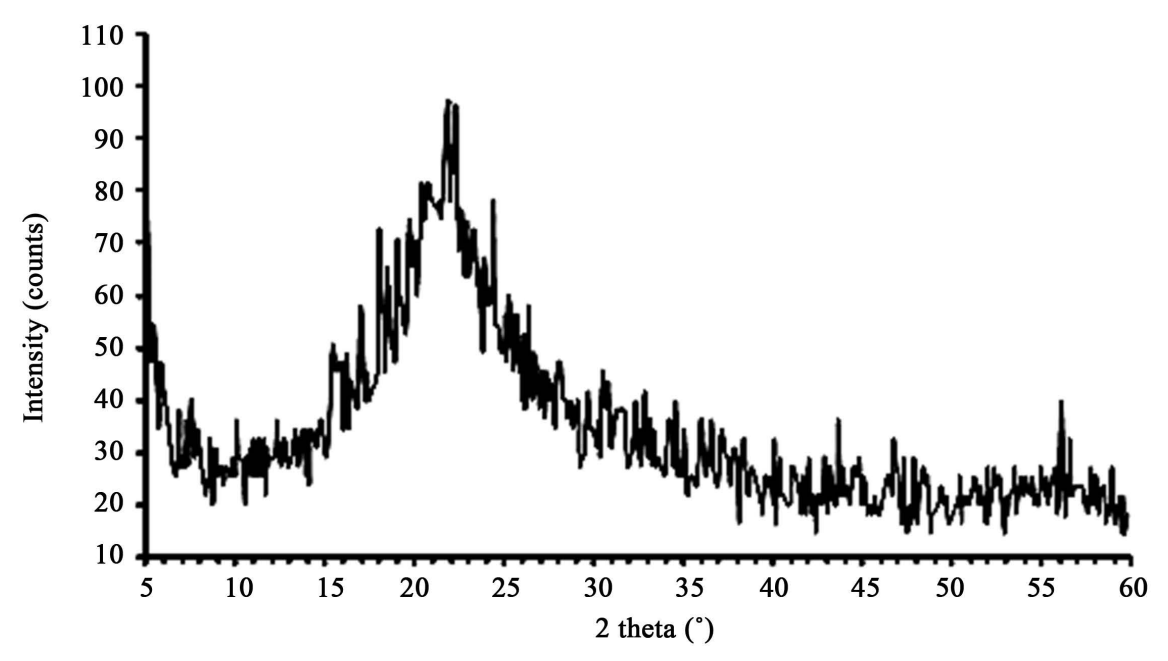

Figure 2. X-Ray Diffraction Pattern of RHA showing the amorphous nature of the material.

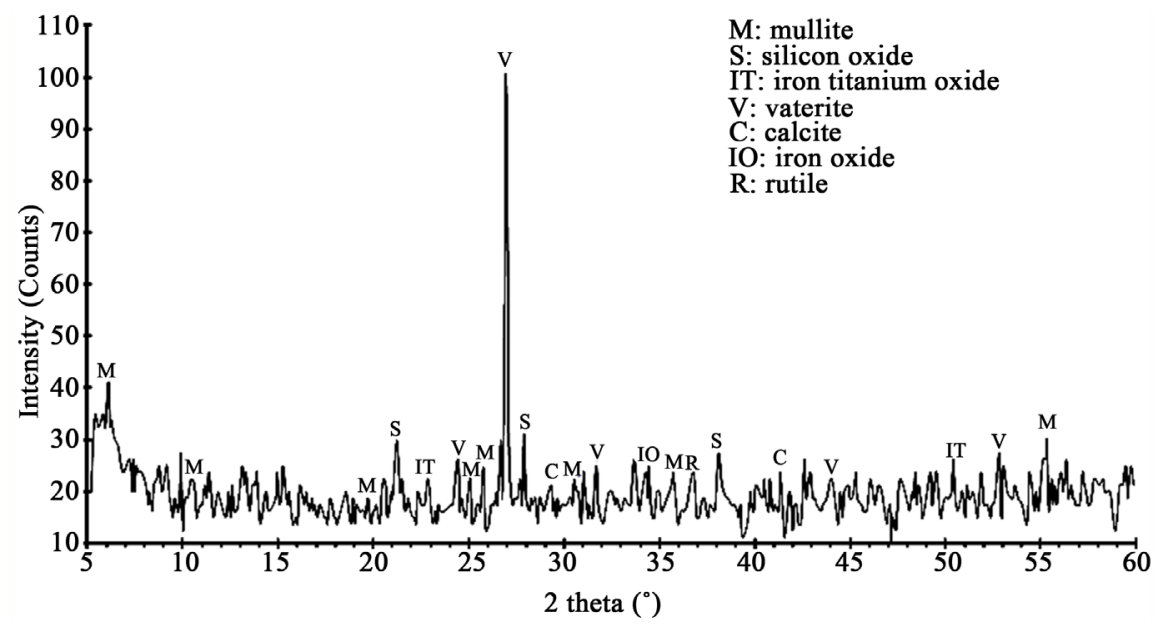

Figure 3. X-ray diffraction pattern of FCBW.

bricks. The presence of crystalline phases such as mullite, quartz, calcite and vaterite, indicated that the firing temperature of bricks favored the crystallization of a part of metakaolin into mullite which is obtained after $1000^{\circ} \mathrm{C}$ [25]. Iron oxide $\left(\mathrm{Fe}_{2} \mathrm{O}_{3}\right)$, rutile $\left(\mathrm{TiO}_{2}\right)$ and ilmenite $\left(\mathrm{FeTiO}_{3}\right)$ were also present as minor phases.

\subsection{Characteristics of Commercial Sodium Silicate and RHA-NaOH Gel}

Results of FTIR spectroscopy using ATR performed on RHA-NaOH gel and commercial sodium silicate are presented in Figure 4. The characteristic peaks of commercial sodium silicate are represented in $\mathrm{RHA}-\mathrm{NaOH}$ gel. The $\mathrm{OH}$ vibration band is observed at $3300 \mathrm{~cm}^{-1}$ for commercial sodium silicate whereas that from RHA-NaOH gel appeared at $3200 \mathrm{~cm}^{-1}$. The bending of water molecules is identified at $1620 \mathrm{~cm}^{-1}$ in the commercial sodium silicate and at 1630 $\mathrm{cm}^{-1}$ in RHA-NaOH gel. The common peak of sodium silicate solutions which is 


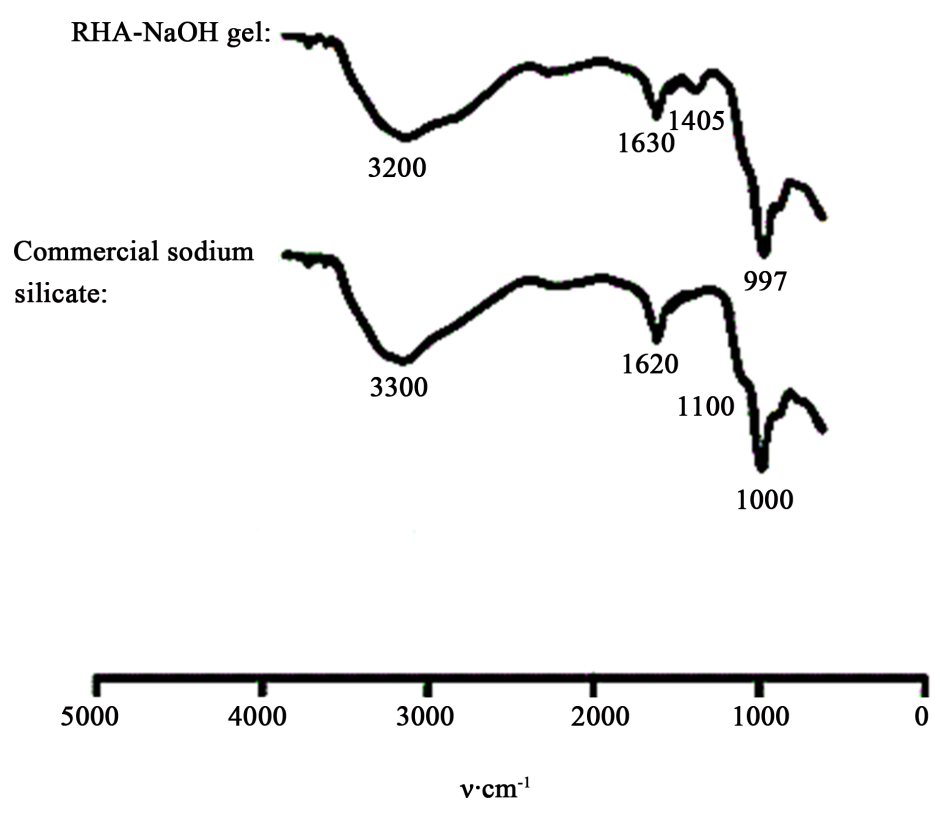

Figure 4. FTIR Spectra of commercial sodium silicate and sodium silicate from RHA.

characterized by the asymmetric stretching of Si-O-Si bonds of the structural units on the ATR-FTIR spectra appears in the region $850-1200 \mathrm{~cm}^{-1}$ [26] [27]. This band is observed at $997 \mathrm{~cm}^{-1}$ for commercial sodium silicate and at 1000 $\mathrm{cm}^{-1}$ for RHA- $\mathrm{NaOH}$ gel, indicating the predominance of Q2 units. This can be justified by the fact that the first solutions appear more depolymerized. The weak peak at about $1100 \mathrm{~cm}^{-1}$ is attributed to Q3 units. This peak is more pronounced on the FTIR spectra of commercial sodium silicate compared to the one from RHA-NaOH gel. This implies that commercial sodium silicate contains more reactive silica than $\mathrm{RHA}-\mathrm{NaOH}$ gel.

\subsection{Characteristics of Products}

\subsubsection{FTIR Analysis}

FTIR spectra of series A, B and C are shown in Figure 5. Results of the products with 100 and $105 \mathrm{~g}$ of FCBW powder were not obtained because of the efflorescence phenomena. All FTIR spectra of the geopolymer matrices with S2 and various amount of FCBW presented common features compared to those from $\mathrm{S} 1$ at the same conditions in the range of $3387-3462 \mathrm{~cm}^{-1}$ and $1637-1662 \mathrm{~cm}^{-1}$. These corresponding bands are attributed respectively to the stretching and bending vibrations of $\mathrm{O}-\mathrm{H}$ bonds, which result from the water molecules that are present either on absorbed surfaces or entrapped in the 3D polymeric structure cavities [28] [29] [30]. The absorption bands appearing in the region 1404 $1419 \mathrm{~cm}^{-1}$ are attributed to the asymmetric stretching vibration of carbon dioxide molecules $\mathrm{CO}_{2}$, which are found in all FTIR spectra samples and probably due to unreacted $\mathrm{Na}^{+}$from alkaline solution which was carbonated by $\mathrm{CO}_{2}$ from ambient air. However, the influence of both nature of used alkaline activators and amount of precursor materials on $\mathrm{Si}-\mathrm{O}-\mathrm{T}$ (where $\mathrm{T}=\mathrm{Si}, \mathrm{Al}$ ) vibrations, were investigated. In fact, the concerned band is ascribed to the formation of 

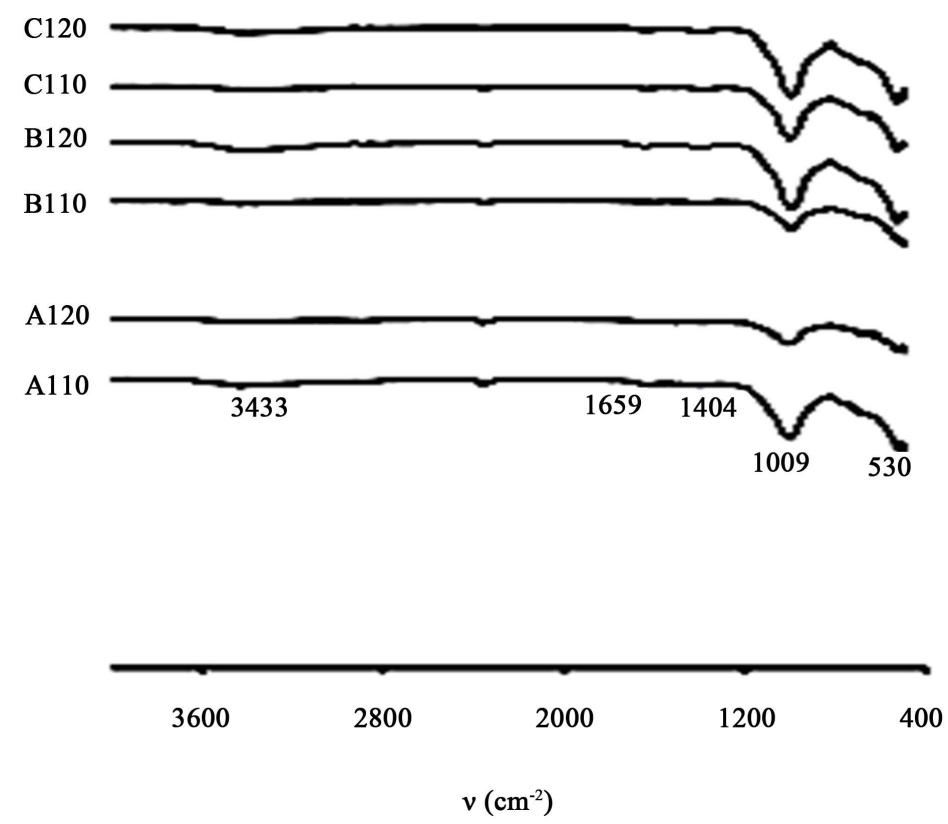

Figure 5. FTIR Spectra of geopolymers for series A, B and C.

aluminosilicate gel. These mainly included the asymmetric stretching of $\mathrm{Si}-\mathrm{O}-\mathrm{Al}$ and Si-O-Si bonds at $\sim 1000 \mathrm{~cm}^{-1}$ [31] [32] and the Al-O vibrations at $\sim 520 \mathrm{~cm}^{-1}$. The variation of FCBW contents from 110 to $120 \mathrm{~g}$ gives rise to a shift of $\mathrm{Al}-\mathrm{O}$ bands from 530 to $542 \mathrm{~cm}^{-1}$ for A, 525 to $538 \mathrm{~cm}^{-1}$ for B and 538 to $536 \mathrm{~cm}^{-1}$ for $\mathrm{C}$, relatively, which are higher than the common value observed with metakaolin as starting material. This band shifts toward the higher wavenumbers in cases of series $\mathrm{A}$ and $\mathrm{B}$ thus indicates less $\mathrm{Al}$ inclusions in their structure suggesting more unreacted FCBW particles while a slight decrease of wavenumbers observed in the case of series $\mathrm{C}$ can be related to the slow dissolution of FCBW particles in S2. The absorption bands assigned to asymmetric stretching of $\mathrm{Si}-\mathrm{O}-\mathrm{Al}$ and $\mathrm{Si}-\mathrm{O}-\mathrm{Si}$ bonds for specimens of series A, B and C appears respectively at 1009, 999 and $1005 \mathrm{~cm}^{-1}$ with $110 \mathrm{~g}$ of FCBW and at 1007, 1003 and 989 $\mathrm{cm}^{-1}$ with $120 \mathrm{~g}$ of FCBW. This suggests that a geopolymerisation reaction took place with both alkaline activators S1 and S2 in the presence of FCBW powder.

\subsubsection{Bi-Axial Four-Point Flexural Strengths}

The bi-axial four point flexural strengths of geopolymer specimens of the three series A, B and C, are shown in Figure 6. The values of flexural strengths of the FCBW based geopolymers using S2 can be compared with the ones obtained with S1 at different amount of FCBW. Specimens of series B present values of strength ranging from 7.5 to $10 \mathrm{MPa}$, with a maximum at $9.3 \mathrm{MPa}$, which correspond to an amount of FCBW of $105 \mathrm{~g}$. However, for series C, the strength increases with the amount of FCBW added, but remains lower than those of series $\mathrm{B}$ (ranging from 4 to $7 \mathrm{MPa}$ ), thus indicating that an addition of FCBW in the matrix gel will improve the flexural strength. As confirmed by FTIR spectra, commercial sodium silicate has Q2 and Q3 while RHA-NaOH gel contains only Q2 species thus conferring less available and reactive silica particles in latter. In 


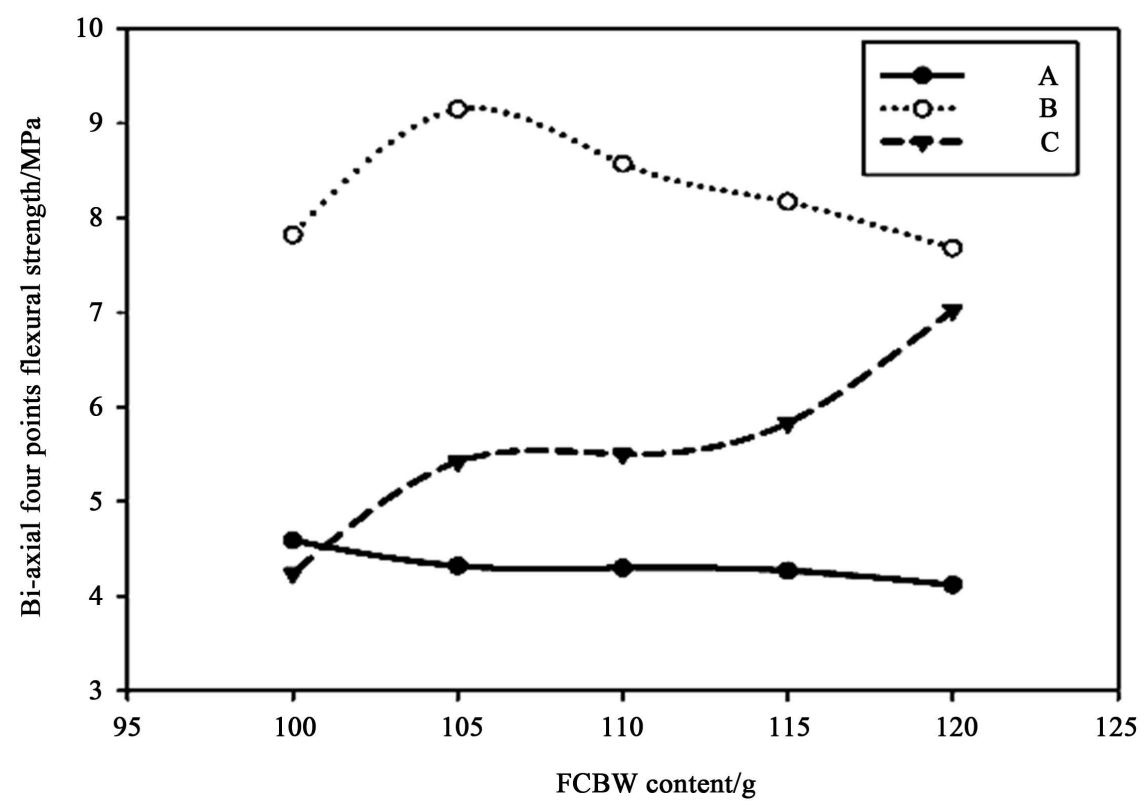

Figure 6. Bi-axial four point flexural strength of FCBW-based geopolymers: series A, B and $\mathrm{C}$ as a function of FCBW added.

accordance with Bernal et al. [33], specimens of series C, which were prepared with S2 at different amount of FCBW, contain undissolved silica particles due to a partial dissolution of some reactive phases present in RHA, delaying in general the kinetic rate of reaction of geopolymerization. Thus the unreacted silica particles act as coarse aggregates in the matrix influencing directly the shift of the flexural strength towards slightly lower values. Moreover, flexural strength values of specimens of series A (ranging from 4 to $5 \mathrm{MPa}$ ) are the lowest. This is coherent with their coarsening microstructure observed due to the unsieved aspect of FCBW used.

\subsubsection{Bulk Density}

The variation in bulk density as a function of FCBW content in various series of gepolymers is presented in Figure 7. The trend of curves is similar to that of flexural strength. The result is in accordance with that obtained by Emdadi et al. [34]. Decrease in bulk density is observed in specimens of series A and B, while increase is observed in that of series $\mathrm{C}$. The less poly-condensation process in geopolymers with RHA-NaOH activator yielded to more unreacted solids that acted as fillers in the mixture and caused increase in bulk density. Results revealed that the change in densities is also influenced by the nature of alkaline activator solutions.

\subsubsection{Water Absorption}

Figure 8 shows the percentage (\%) of water absorption of various series of geopolymers. For series B, values of water absorption range from $14.58 \%$ to $16.13 \%$ corresponding respectively to a minimum and maximum absorption. Specimens of series $\mathrm{C}$ have the highest values of water absorption ranging from $17.2 \%$ to $17.9 \%$. Unreacted gel and undissolved silica contributed to increase water 


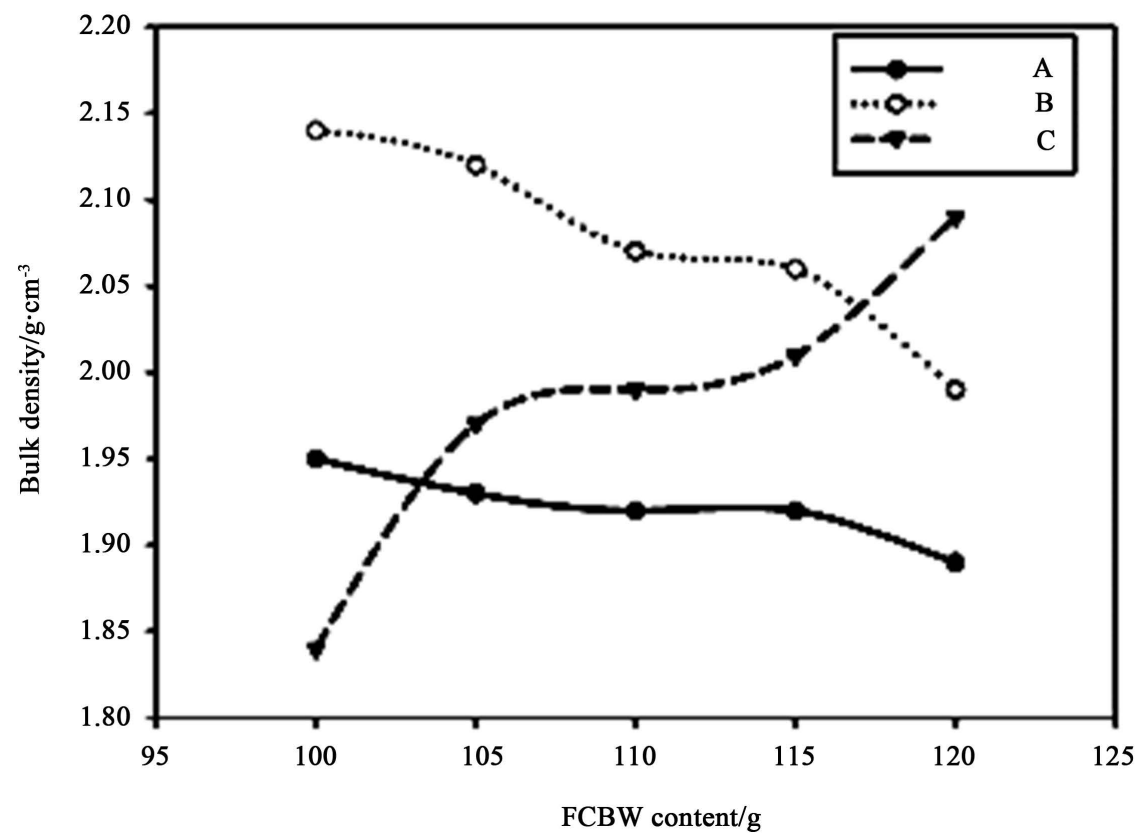

Figure 7. Bulk density of FCBW based geopolymers: series A, B and C as a function of FCBW added.

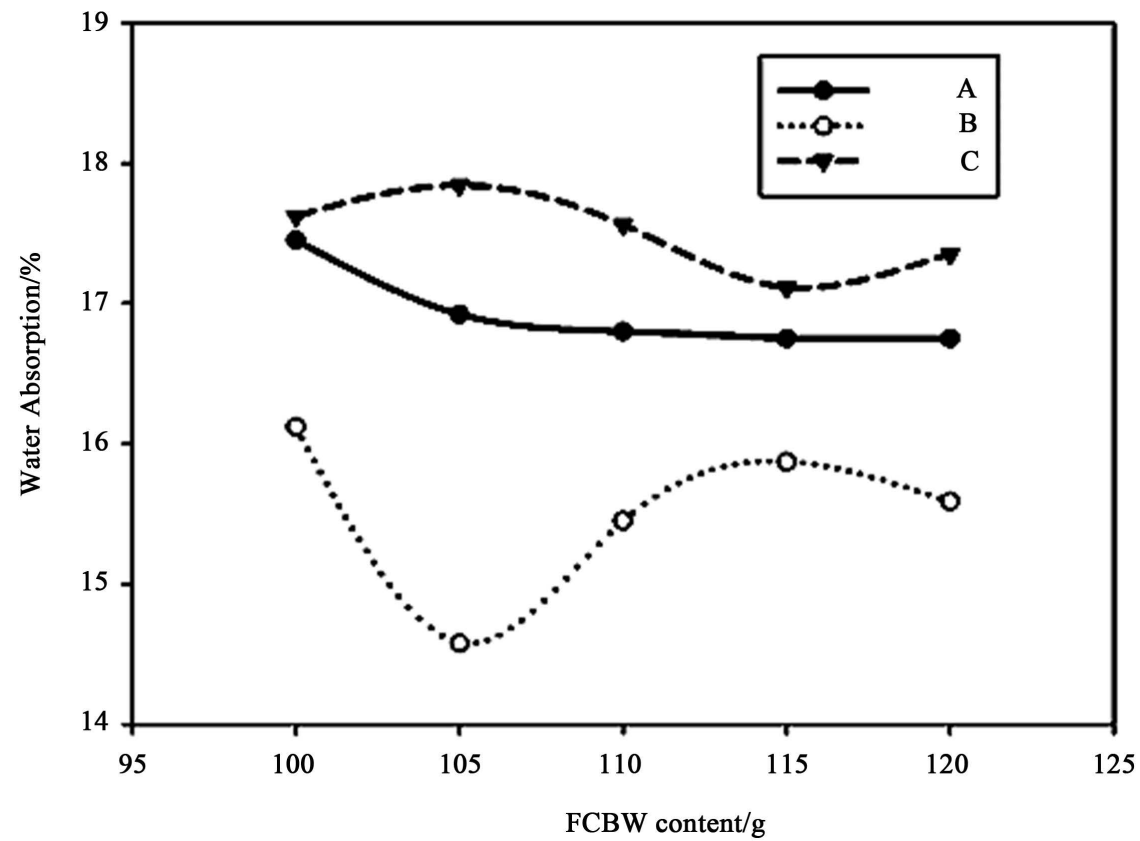

Figure 8. Water absorption of FCBW-based geopolymers: series A, B and C as a function of FCBW added.

absorption geopolymer with $\mathrm{RHA}-\mathrm{NaOH}$ activator. Compared to Figure 6, the high water absorption of specimens of series $\mathrm{C}$ does not have a detrimental effect on their flexural since no decrease in that property was observed. Explanation of this behavior could be in the nature of bonds and geopolymerisation phases obtained when RHA-NaOH activator is used compared to commercial sodium silicate. 


\subsubsection{SEM Analysis}

The micrographs shown in Figure 9 illustrate the microstructure of the geopolymer made from fired clay brick wastes. In the alkaline media, the amorphous fraction of the fired clay is dissolved to form aluminosilica oligomers that progressively polycondensed to $3 \mathrm{D}$ network with amorphous and porous structure. This amorphous structure of geopolymer dominates the matrices of the series $\mathrm{B}$ and $\mathrm{C}$ and can be explained by the fact that during the sieving of FCBW, a major fraction of potential unreacted silica particles was removed. That increased the content of the solid precursor that is going to be geopolymerized. This can justify the good homogeneous aspect of the micrographs with better compactness which is the demonstration of the extent of geopolymerization. The gel-like structure as observed is typical to that described in the literature [6] [9] for the silica-rich based geopolymer cement. The gel itself is comprised of colloidalized, globular units closely bonded together at their surfaces. Between the grains and particles a nanostructured porosity exist which is characteristic of the gel from the geopolymerization. The fractured surfaces of the micrographs give a clear idea on the density and strength achieved by the series B and C. Low capillary porosity and the absence of microcracks in those matrices are in agreement with the phase evolution (Figure 8) confirming the good extent of polycondensation and particles packing. The compactness of the microstructure is significant in $\mathrm{B}$ with respect to $\mathrm{C}$. This is linked to the level of solubility in the two alkaline activators. The absence of significant nanosized silica in S2 delayed in general the
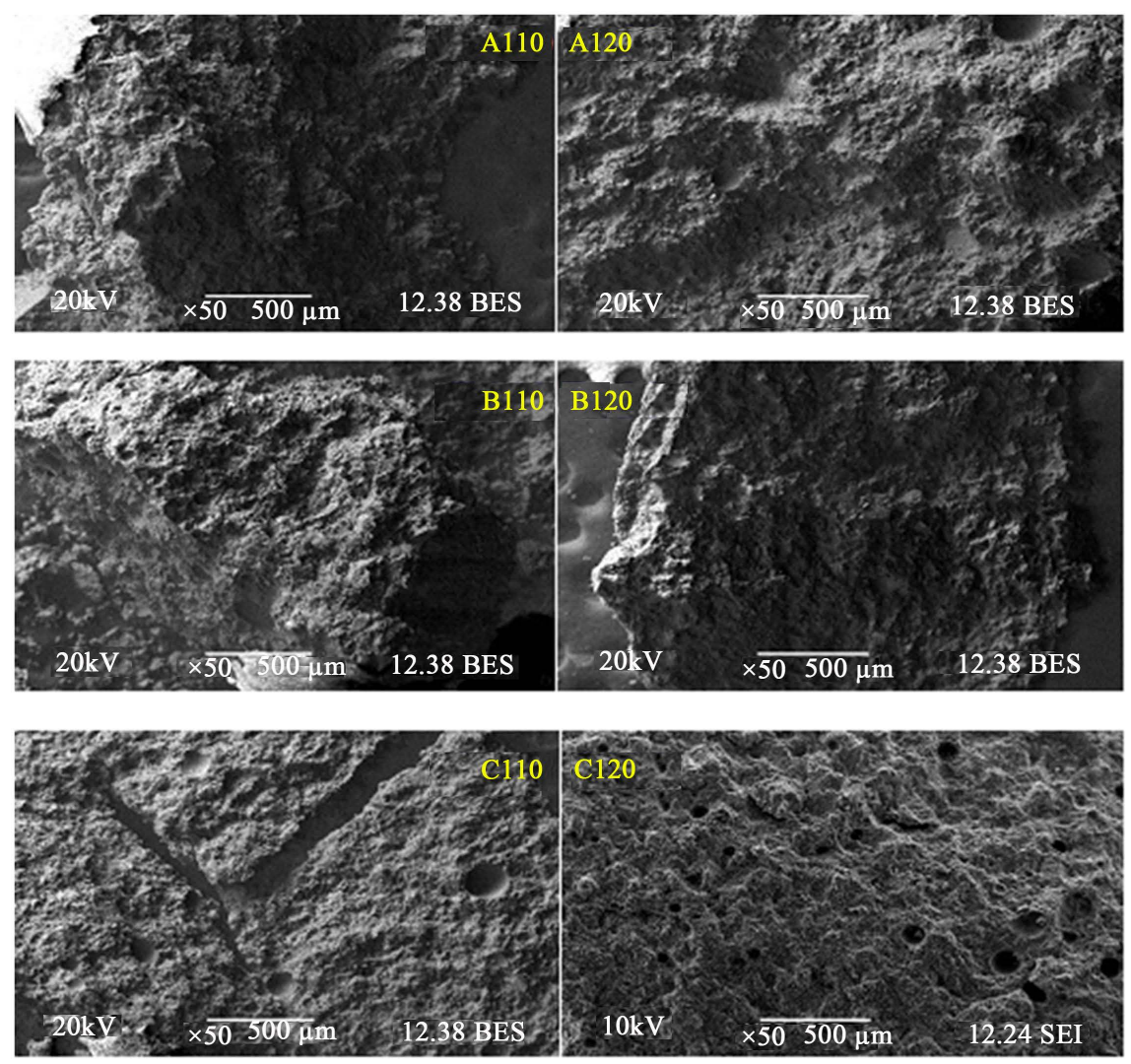

Figure 9. Microstructures of geopolymers of series A, B and C. 
kinetics of the reaction of geopolymerization. The absence of these nanosilica also increase the voids and enhance the coarsening of the microstructure. This can be easily correlated with the mechanical strength (Figure 6).

The specimens of series A show more coarsening microstructure with respect to those of series B and C. It can be noted that series A is produced with unsieved FCBW. This increases the silica fraction in the matrix, with the undissolved fraction acting as fine aggregates contributing to develop discontinuity into the microstructure of the gel-like structure of geopolymer. Although the gel in series B demonstrated a good adhesion as can be observed in Figure 9, the high volume of capillary pores and the discontinuity created by the aggregates are responsible for the less densification and relative low strength of series $\mathrm{A}$. This was evident as into the matrix of FCBW, the fraction of clayey minerals is relatively low and only that clayey fraction can be responsible for the matrix strengthening of the geopolymer composites. It is then evident that the appropriate microstructure that guarantee good strength, high density and low porosity as in the case with series B with $105 \mathrm{~g}$ of solid precursor and with respect to series $\mathrm{C}$ with $120 \mathrm{~g}$ of solid precursor, should consider the clayey/aggregates ratio of the FCBW so that some adjustment in the processing or the composition design can be done for the optimization of the characteristics of the final product.

\section{Conclusions}

From the investigations carried out in the present study, the following conclusions can be drawn:

- Geopolymer products can be obtained from crushed fired clay bricks waste and RHA-NaOH solution;

- RHA-NaOH gel can be used as an alternative to commercial sodium silicate in the geopolymerization process, to obtain geopolymer products with characteristics which are similar or higher compared to commercial sodium silicate when used, appropriate filtration process should be applied to RHA-NaOH gel to reduce impurities as undissolved species. Study on the appropriate synthesis method of $\mathrm{RHA}-\mathrm{NaOH}$ gel that gives optimum reactivity of RHA should also be made;

- $\mathrm{RHA}-\mathrm{NaOH}$ gel contains less reactive silica than the commercial sodium silicate;

- To better understand the characteristics of geopolymers with RHA-NaOH gel and FCBW, more investigations should be done on the nature of bonds and reaction products.

\section{Acknowledgements}

The authors of this article acknowledge the support from the Academy of Sciences from the Third World (TWAS): Grant-N ${ }^{\circ}$ 11-024RG/CHE/AF/AC-G; UNESCO FR: 3240262695. 


\section{References}

[1] Favier, A. (2013) Mécanisme de prise et rhéologie de liants géopolymères modèles. Thèse de doctorat, Université de Paris-Est, Paris.

[2] Puertas, F., García-Díaz, I., Barba, A., Gazulla, M.F., Palacios, M. Gómez, M.P. and Martínez-Ramírez, S. (2008) Ceramic Wastes as Alternative Raw Materials for Portland Cement Clinker Production. Cement and Concrete Composites, 30, 798805. https://doi.org/10.1016/j.cemconcomp.2008.06.003

[3] Habert, G., D’Espinose de Lacaillerie, J.B. and Roussel, N. (2011) An Environmental Evaluation of Geopolymer Based Concrete Production: Reviewing Current Research Trends. Journal of Cleaner Production, 19, 1229-1238. https://doi.org/10.1016/j.jclepro.2011.03.012

[4] Rodriguez, E.D., Bernal, S.A., Provis, J.L., Jordi, P., Monzo, J.M. and Borrachero, M.V. (2013) Effect of Nanosilica-Based Activators on the Performance of an AlkaliActivated Fly Ash Binder. Cement and Concrete Composites, 35, 1-11. https://doi.org/10.1016/j.cemconcomp.2012.08.025

[5] Davidovits, J. (1991) Geopolymers. Journal of Thermal Analysis, 37, 1633-1656. https://doi.org/10.1007/BF01912193

[6] Davidovits, J. (2008) Geopolymer Chemistry and Applications. Geopolymer Institute, Saint-Quentin.

[7] Elimbi, A., Tchakoute, H.K. and Njopwouo, D. (2011) Effects of Calcination Temperature of Kaolinite Clays on the Properties of Geopolymer Cements. Construction and Building Materials, 25, 2805-2812.

https://doi.org/10.1016/j.conbuildmat.2010.12.055

[8] Al Bakri, M.M., Mohammed, H., Kamarudin, H., KhairulNiza, I. and Zarina, Y. (2011) Review on Fly Ash-Based Geopolymer Concrete without Portland Cement. Journal of Engineering and Technology Research, 3, 1-4.

[9] Kamseu, E., Leonelli, C., Perera, D.S., Melo, U.C. and Lemougna, P.N. (2009) Investigation of Volcanic Ash Based Geopolymers as Potential Building Materials. International Ceramics, 58, 136-140.

[10] ReighCerdá, L., Tashima, M.M., Borrachero, M.V., Monzó, J., Cheeseman, C.R. and Payá, J. (2013) Properties and Microstructure of Alkali-Activated Red Clay Brick Waste. Construction and Building Materials, 43, 98-106. https://doi.org/10.1016/j.conbuildmat.2013.01.031

[11] Provis, J.L. (2009) Activating Solution Chemistry for Geopolymers, Geopolymers: Structures, Processing, Properties and Industrial Applications. Woodhead Publishing, Abingdon, 50-71.

[12] Kalapathy, U., Proctor, A. and Shultz, J. (2002) An Improved Method for Production of Silica from Rice Hull Ash. Bioresource Technology, 85, 285-289.

[13] Foletto, E.L., Gratieri, E., De Oliveira, L.H. and Jahn, S.L. (2006) Conversion of Rice Hull Ash into Soluble Sodium Silicate. Materials Research, 9, 335-338. https://doi.org/10.1590/S1516-14392006000300014

[14] Zivica, V. (2004) High Effective Silica Fume Alkali Activator. Bulletin of Materials Science, 27, 179-182. https://doi.org/10.1007/BF02708502

[15] Affandi, S., Setyawan, H., Winardi, S., Purwanto, A. and Balgis, R. (2009) A Facile Method for Production of High-Purity Silica Xerogels from Bagasse Ash. Advanced Powder Technology, 20, 468-472.

[16] De Sousa, A., Visconte, L., Mansur, C. and Furtado, C. (2009) Silica Sol Obtained from Rice Husk Ash. Chemistry \& Chemical Technology, 3, 321-326. 
[17] Xiong, L., Sekiya, E.H., Sujaridworakun, P., Wada, S. and Saito, K. (2009) Burning Temperature Dependence of Rice Husk Ashes in Structure and Property. Journal of Metals, Materials and Minerals, 19, 95-99.

[18] Sore, S.O., Messan, A., Prud'homme, E., Escadeillas, G. and Tsobnang, F. (2016) Synthesis and Characterization of Geopolymer Binders Based on Local Materials from Burkina Faso-Metakaolin and Rice Husk Ash. Construction and Building Materials, 124, 301-311.

[19] Behnood, A., Modiri Gharehveran, M., GozaliAsl, F. and Ameri, M. (2015) Effects of Copper Slag and Recycled Concrete Aggregate on the Properties of CIR Mixes with Bitumen Emulsion, Rice Husk Ash, Portland Cement and Fly Ash. Construction and Building Materials, 96, 172-180.

[20] Yang, W., Xue, Y., Wu, S., Xiao, Y. and Zhou, M. (2016) Performance Investigation and Environmental Application of Basic Oxygen Furnace Slag - Rice Husk Ash Based Composite Cementitious Materials. Construction and Building Materials, 123, 493-500.

[21] Yoshizawa, S., Tanaka, M. and Shekdar, A.V. (2004) Global Trends in Waste Generation. In: Recycling, Waste Treatment and Clean Technology, TMS Mineral, Metals and Materials Publishers, 1541-1552.

[22] Jihwan, K., Dong, J.K. and Goangseup, Z. (2013) Improvement of the Biaxial Flexure Test Method for Concrete. Cement and Concrete Composites, 37, 154-160.

[23] ASTMC 830-00 (2006) Standard Test Methods for Apparent Porosity, Liquid Absorption, Apparent Specific Gravity and Bulk Density of Refractory Shapes by Vacuum Pressure. ASTM International.

[24] Kamath, S.R. and Proctor, A. (1998) Silica Gel from Rice Hull Ash: Preparation and Characterization. Cereal Chemistry, 75, 484-487. https://doi.org/10.1094/CCHEM.1998.75.4.484

[25] Sabir, B.B., Wild, S. and Bail, J. (2001) Metakaolin and Calcined Clays as Pozzolans for Concretes: A Review. Cement and Concrete Composites, 23, 441-454.

[26] Halasz, I., Agarwal, M., Li, R. and Miller, N. (2007) Vibrational Spectra and Dissociation of Aqueous $\mathrm{Na}_{2} \mathrm{SiO}_{3}$ Solutions. Catalysis Letters, 117, 34-42. https://doi.org/10.1007/s10562-007-9141-6

[27] Gaggiano, R., De Graeve, I., Mol, J.M.C., Verbeken, K, Kestens, L.A.I. and Terryn, H. (2013) An Infrared Spectroscopic Study of Sodium Silicate Adsorption on Porous Anodic Alumina. Surface Interface Analysis, 45, 1098-1104. https://doi.org/10.1002/sia.5230

[28] Tognonvi, T.M., Soro, J., Gelet, J.L. and Rossignol, S. (2012) Physico-Chemistry of Silica/Na Silicate Interactions during Consolidation. Part 2: Effect of $\mathrm{pH}$. Journal of Non-Crystalline Solids, 358, 492-501.

[29] White, C.E., Provis, J.L., Llobet, A.L., Proffen, T. and van Deventer, J.S.J. (2011) Evolution of Local Structure in Geopolymer Gels: An in Situ Neutron Pair Distribution Function Analysis. Journal of the American Ceramic Society, 94, 3353- 3532. https://doi.org/10.1111/j.1551-2916.2011.04515.x

[30] Tchakoute, H.K. (2013) Elaboration et caractérisation des ciments géopolymères à base de scories volcaniques. Thèse de doctorat.

[31] Panias, D., Giannopoulou, I. and Perraki, T. (2007) Effect of Synthesis Parameters on the Mechanical Properties of Fly Ash-Based Geopolymers. Colloids and Surfaces A: Physico-Chemical Engineering Aspects, 301, 246-254.

[32] Fernandez, J.A. and Palomo, A. (2005) Composition and Microstructure of Alkali Activated Fly Ash Binder: Effect of the Activator. Cement Concrete Research, 35, 1984-1992. 
[33] Bernal, S.A., Rodriguez, E.D., Mejia de Gutiérrez, R., Provis, J.L. and Delvasto, S. (2012) Activation of Metakaolin/Slag Blends Using Alkaline Solutions Based on Chemically Modified Silica Fume and Rice Husk Ash. Waste and Biomass Valorization, 3, 99-108. https://doi.org/10.1007/s12649-011-9093-3

[34] Emdadi, Z., Asim, N., Yarmo, M.A., Shamsudin, R. and Alghoul, M.A. (2015) The Effect of Mix Composition on the Water Absorption, Density and Compressive Strength of Rice Husk Based Geopolymers. 5th International Conference on Environment Science and Engineering, Vol. 83, 1-5.

Submit or recommend next manuscript to SCIRP and we will provide best service for you:

Accepting pre-submission inquiries through Email, Facebook, LinkedIn, Twitter, etc. A wide selection of journals (inclusive of 9 subjects, more than 200 journals)

Providing 24-hour high-quality service

User-friendly online submission system

Fair and swift peer-review system

Efficient typesetting and proofreading procedure

Display of the result of downloads and visits, as well as the number of cited articles Maximum dissemination of your research work

Submit your manuscript at: http://papersubmission.scirp.org/

Or contact msa@scirp.org 